\title{
THE INFLUENCE OF LAND COVER ON THE SPATIAL DISTRIBUTION OF FIRE SITES: A CASE STUDY OF LÓDZKIE VOIVODESHIP, POLAND
}

\begin{abstract}
The paper continues from previous joint studies and their practical application at the confluence of human geography, safety-related research and Geographic Information Systems (GIS). The objective of the study was to identify the land cover types most at risk from fire. The study has contributed an original angle by taking into account various land cover types with a potential influence on the distribution of fires geocoded at the address level. The analysis considered 27,651 fire interventions, as recorded by the Polish State Fire Service between 2014 and 2016 in the country's central region known as Łódzkie Voivodeship. The main methods employed include various GIS tools, including Voronoi tessellation (to identify the areas most at risk of fire) and the fire location quotient (FLQ, a measure of the colocation between the number of fires and land cover). The most important conclusion is that of all the land cover types considered in the study, the built-up area type, especially the multi-family residential and retail and service area subtypes, was virtually the only one with a strong influence on the location of fires. The fire high-risk areas (FH-RA) identified here were primarily limited to urban areas.
\end{abstract}

Key words: fire incident, GIS, land cover, fire high-risk area, fire location quotient, Łódzkie Voivodeship.

\section{INTRODUCTION. THEORETICAL AND EMPIRICAL BACKGROUND}

Over the millennia, fire has accompanied mankind in its rise to civilisation. When tamed, it offered advantages, but uncontrolled and wild it brought calamity, tragedy and defeat. Fire can ravage vast areas, ruin settlements, and turn crops and forests into ashes. Losses of this kind cannot be fully expressed in any currency or the numbers of dead and injured. They can be minimised only if adequately

\footnotetext{
* Stanisław MORDWA, University of Lodz, Faculty of Geographical Sciences, Institute of the Built Environment and Spatial Policy, Kopcińskiego 31, 90-142, Łódź, Poland; e-mail: stanislaw.mordwa@geo.uni.lodz.pl, ORCID: https://orcid.org/0000-0002-7254-0933

** Małgorzata OSTROWSKA, independent researcher; e-mail: ostrowskamga@gmail.com
} 
equipped and trained fire services respond quickly to fire incidents. Optimisation of the response time and of the efficient deployment of resources demands an accurate identification of the needs in terms of the distribution and operating range of fire service units, which can be obtained through complex analyses performed by local authorities and the fire-service command structures.

The spatial dimension of the distribution and conditions for fire interventions is the subject of research at various spatial scales ranging from national (Eswatini - Dlamini, 2011; New Zealand, UK - Moffat and Pearce, 2013; Poland - Woźniak, 2014), through regional (Espirito Santo - Eugenio et al., 2016; Dalmatia - Jajtić et al., 2019; Mazovia - Kozioł, 2019), areas and districts (West Midlands - Hastie and Searle, 2016; Bodrum - Akay and Sahin, 2019), individual cities or towns (Toronto - Asgary et al., 2010; Warsaw - Mazur, 2014; Vilnius - Vasiliauskas and Beconyte, 2015; Yichun - Guo et al., 2017; Nanjing - Xia et al., 2019), and, finally, to a micro scale of just several buildings (in Jos, Nigeria - Nimlyat et al., 2017). In general, such studies can be divided into those focusing on inhabited areas and those focusing on forest areas.

An example of the application of GIS and remote sensing methods in the analysis of the distribution and causes of fires is a study of the African state of Eswatini (Dlamini, 2011). The author studied the interrelations between a range of factors with a potential impact on the location of fires and their real distribution. He considered altitude above sea level, angle of slope, average annual rainfall, average annual temperature, relative humidity, land ownership, soil category, population density, road density, distance from buildings, presence or absence of domestic animals, and land cover. Dlamini then assessed the fire risk across the country and his resulting map achieved satisfactory levels of similarity when compared with the actual distribution of fires. The author has concluded that land cover has a significant influence on fire risk.

Mazur and Kwasiborski (2013) analysed the distribution of selected detailed characteristics of fires in Poland from reports covering the period 2007-2012. The detailed specifications considered included: the overall number of fires and the number of people affected, both overall and by type of item on fire. The analysis yielded an assessment of the safety and types of items with the highest levels of fire risk. Apparently, as the number of fires reported in this period increased, the number of injured and dead per fire decreased. The highest ratios of victims, both injured and casualties, per fire were reported for residential buildings, which was the third most frequently affected type, after fires in agriculture and transport.

Subject literature often includes a discussion about fire risk assessment in urban areas ${ }^{1}$. Authors tend to consider two main issues: i) how to identify urban areas with a high fire risk/likelihood (Mazur, 2014), or ii) which characteristics of an urban environment are most associated with a fire risk (Jennings, 2013; Vasi-

\footnotetext{
${ }^{1}$ Fire risk is understood as the likelihood or forecasted frequency of occurrence of fires in a given area.
} 
liauskas and Beconytė, 2015). In general, earlier research suggested that the main factors determining the number of fires in urban areas were the social, economic and environmental characteristics of the local community. It was only in the early $21^{\text {st }}$ century, as GIS techniques became sufficiently popular, that researchers also noted other important variables of fire risk. Jennings (2013) offered a review of literature focusing on fire risk factors in US residential areas. He used the review to build a conceptual model of fire risk. According to this model, a fire can be caused by internal factors (inherent in the nature of a given dwelling) or external factors (the physical environment and weather conditions, the character of a neighbourhood, and individual behaviour). The main components of the model included: dwelling characteristics (dwelling materials, structure, age, equipment, content, and electrical fittings); physical environment (setting, vegetation cover, and topography); weather conditions (temperature, wind speed, rainfall/snowfall, and humidity); neighbourhood characteristics (demography, socio-economic status, and cultural practices) and individual behaviour (perception/attitude, values and beliefs, socio-economic status, and cultural background). Other factors with a lesser influence on fire risk included calendar events or group behaviour (family lifecycle, household size, and household composition). The fire risk factors included in this model were successfully tested by the British researchers Hastie and Searle (2016). They focused on analysing the socio-economic and demographic factors correlated with accidental residential fires. The study confirmed that the ethnic structure of a given area (particularly the proportion of Black African-Caribbean residents), and economic deprivation (most notably the levels of wordlessness) are strong indicators of areas with a frequent incidence of fire.

Asgary et al. (2010) published a spatio-temporal analysis of fires in Toronto. He found that fires were the most frequent in the downtown area and along the main streets where city life was at its most intense (and many fires were due to arson). Outside the downtown, fires tended to erupt in lower income areas. The least fires were reported in areas with low population density, with modern houses and with higher incomes. The city centre was also identified as the peak fire area in Warsaw (Poland) by Mazur (2014) and by Mazur and Guzewski (2014). Fire hot spot areas, identified using the kernel density estimation method, were found to coincide with the most densely developed areas. The authors also established that the number one cause of fires in Warsaw was the human factor (73\%). Arson $(35 \%)$ and the careless handling of open fires by adults (15\%) were followed by technical causes (electrical wiring and appliances, and solid-fuel fired heating at $11 \%$ ). A study of the city of Jos in Nigeria found that the number one cause of fires in high-rise buildings was electrical faults (Nimlyat et al., 2017). Hence they recommended that designers and property owners should equip buildings with fire safety measures. These measures should be present, adequate and in locations well known and visible to the inhabitants. In another study, Holborn et al. (2003) concluded that of all the occasional fires reported in London (1996-2000), a half 
(47\%) started with a cigarette or a cigar (followed by kitchen appliances at 14\%); more than a half of the deaths due to fire applied to people aged 60 or more; the most occasional fires started in the lounge or drawing room (33\%), followed by the bathroom (29\%) and the kitchen (20\%).

Xia et al. (2019) used local and global colocation pattern measures to identify the most fire-prone region in Nanjing (China) where fire sites clearly tended to concentrate in certain areas. The study demonstrated that different urban land uses were linked with different types of fire incidents. For example, the incidence of dwelling fires was strongly correlated with the presence of residential areas, while non-residential buildings caught fire most frequently if they adjoined entertainment sites, and vehicle fires occurred in downtown commercial districts.

Forest fires are less frequent than urban incidents, but when they emerge, they can grow considerably. Indeed, to a firefighter a forest is a large stock of fuel. Forest fires also cause long-lasting changes in the ecosystem as forests take much longer to recover than human settlements. For these reasons, forest monitoring and rapid reaction to incidents is a very important objective for fire services. This paper uses the Brazilian state of Espírito Santo to discuss the development of a model for mapping forest fire risk (Eugenio et al., 2016). Maps of this type are among the most important environmental protection instruments. The GIS-based model weighted two types of characteristics: physical (e.g. slope angle, land cover, and proximity of road infrastructure) and climatic (e.g. precipitation, temperature, water deficit, and evaporation). The resulting map divided the whole area into five risk levels: low, medium, high, very high, and extreme. Using this approach and other studies, fire hazard factors in forests can be divided into four groups: stand/vegetation structure, topographic factors, proximity/distance to ... (e.g. residential area, roads, water bodies), and climatic factors (Paysen et al., 2000; Moffat and Pearce, 2013; Akay and Erdogan, 2017; Guo et al., 2017; Akay and Sahin, 2019; Schaefer and Magi, 2019; Feurdean et al., 2020). Population density is also considered to help assess transitional zones where residential development mixes with forests (Guo et al., 2017). Among the factors associated with stand structure, the following are considered important: tree species, crown closure, and tree stage. Other groups of factors include: topographic factors, such as ground slope, aspect (as a function of humidity and temperature), and elevation; climatic factors, including temperature, humidity, precipitation, and wind; and, finally, proximity to roads, railways, settlements, and water resources. There are also the kinds of circumstances that impact the fire risk in forests and are modified by seasons, days of the week, time of day, remaining weather conditions, or human presence or lack thereof in the forest (Feurdean et al., 2020). Researchers assign a different weighting to each factor depending on the area of study. Akay and Sahin (2019), for instance, selected tree species, tree stage and water resources as the most important variables in the Bodrum province, Turkey. Yichun, in turn, selected ground slope, elevation, distance from a railway, water resources, and humidity in the Chinese study (Guo et al., 2017). 
A separate category of firefighting-related papers, interesting from the geographer's perspective, considers the deployment of fire fighting services. Fairness and efficiency are the two main criteria that tend to be used in determining the location for new fire stations (FS) or in evaluating existing FS networks. Fairness requires that the same level of protection be provided to everyone, while efficiency prioritises the most efficient ways of distributing the available hardware and personnel resources. A frequent measure of the efficiency and effectiveness of fire fighting services is their response time (from receiving a fire incident report to arriving on the site of the fire) which can minimise the risk to life, health and property. In their study of the optimal FS location in China, Zhang and Jiang (2011) indicated the optimal fire-service response time at 5 minutes. A similar result was obtained by Yang et al. (2001) for Derbyshire (UK) as the response time varied depending on the fire risk category between 4-5 minutes for high-risk incidents and 10-20 minutes for low risk fires.

Various researchers build functional and optimisation models of FS distribution. For instance, Huang et al. (2005), Yang et al. (2007), and Zhang and Jiang (2011) have built their models by stressing the need to minimise the travel time from an FS to an accident site, maximise service coverage, distance balancing (distribution of FSs), minimise the overlap of FS service areas, minimise the distance between an FS and an accident site, minimise the total setup costs of an FS, and minimise associated costs. They did not, however, consider such objectives as, for example: determining a reasonable number of FSs, minimising the distance between an FS and high-risk areas, maximising the service for high-risk areas (Erden and Coşkun, 2010) in identifying the location.

In this study we undertook to understand the spatial relationships between the distribution of fires and land cover types using the colocation indicator (fire location quotient, FLQ). To derive spatial colocation patterns, we studied the distribution of fire sites classified under three size groups versus 16 land cover types and subtypes. The study used this distribution of fire sites to identify an area with the highest fire risk and this area was further researched using FLQ.

\section{THE DATA AND METHODS}

\subsection{Data}

For the purpose of this study, two types of data and information were gathered about fire interventions and about the land cover in the Lódzkie Voivodeship (region) in central Poland. The fire intervention data, spanning 2014-2016, was released by the Regional HQ of the State Fire Service (Komenda Wojewódzka 
Państwowej Straży Pożarnej) in the city of Łódź. The information was compiled by the Operational Department of the Fire Service and exported from the Command Support System ST ${ }^{2}$ (SWD-ST) database into a spreadsheet. The details contained therein included: the time of incoming report, unit ID, fire type, geographic latitude and longitude, number of crews, damage, and the address and type of property affected. The Fire Service only started gathering fire intervention data in the system in 2014 and this is the reason for selecting the 2014-2016 for the study. The breakdown of the information contained in the system is shown in Table 1.

The type of fire data obtained for the Lódzkie Voivodeship posed two problems. The first was the need to convert geographical coordinates into the GPS - WGS 84 (code 4326) system and then to export the point layer in the .shp format arranged in the PUWG 92, CS92 (code 2180) structure. Apparently due to inaccuracies in the original recording of the coordinates the resulting approximate locations of the fire sites were not entirely precise. Indeed, the rounding of seconds in coordinate data shifted locations by between ten and several tens of metres away from actual addresses, if an address was even available in the first place. Indeed, the address data was also lacking in terms of accuracy and sometimes missing altogether, which forced the authors to limit themselves in identifying fire site locations to just providing converted geographical coordinates.

When a total of 27,651 incidents were geocoded, $142(0.51 \%)$ 'fell outside' of the voivodeship borders. All of these fortunately had accurate addresses and could be brought back in. Additionally, of the 76 interventions that 'fell out' of their district boundaries, $62 \%$ could be restored to the right locations. A certain degree, probably a minor one, of location error should be expected in any further analysis of the point data for fire interventions.

There is an interesting research project involving a breakdown of the sites affected by fire into eight categories that are proposed in the Operating manual ( $\mathrm{Po}$ dręcznik uzytkownika Systemu...(2014)) used in operating the SWD-ST database. The author, however, has not succeeded in obtaining access to the categorisation, and the actual database only featured descriptive characteristics of these sites. Appealing as an analysis of this categorisation would have been, the sheer volume of records that would have to be processed manually forced the author not to pursue this line of action.

\footnotetext{
${ }^{2}$ Command Support System ST (SWD-ST) is an Oracle-based IT system. It contains information about incidents, time, space and statistical data on the resources and personnel used, the type and causes of the intervention, and its results. The system is used to exchange information between PSP (State Fire Service) units and with the external world. It supports the handling of cases in real time and the application of personnel and equipment of both the professional and volunteer fire units (Podręcznik użytkownika Systemu..., 2014).
} 
Table 1. Scheme for a fire intervention database provided by the Regional Headquarters of the State Fire Service (KW PSP)

\begin{tabular}{|c|c|}
\hline Field & Description \\
\hline Code & - Unique variable identifying the incident \\
\hline $\begin{array}{l}\text { Incident reporting } \\
\text { time }\end{array}$ & $\begin{array}{l}\text { - dd-mm-yyyy hh:mm:ss, } \\
\text { - Automatically generated by the system upon the first saving of the } \\
\text { incident file }\end{array}$ \\
\hline Unit & - Main unit responsible for the incident \\
\hline Type & - Selected from: fire, local threat, false alarm \\
\hline Size & $\begin{array}{l}\text { - P/M - small fire (destruction or burning down of items such as: } \\
\text { movable items, storage sites, machines and equipment up to } 70 \text { sq. } \mathrm{m} \\
\text { or } 350 \text { cubic m, forests, crops, grasses, peat bogs or idle land up to } \\
1 \text { ha), } \\
\text { - } \mathrm{P} / \mathrm{S} \text { - medium-size fire (affecting items with an area from } 71 \text { sq. m to } \\
300 \text { sq. m, and volume from } 351 \text { cubic } \mathrm{m} \text { to } 1,500 \text { cubic } \mathrm{m} \text {, or areas } \\
\text { with a size from } 1 \text { ha to } 10 \text { ha; intervention involving simultaneous } \\
\text { deployment of } 5-12 \text { streams*), } \\
\text { - P/D - large-size fire (affecting items with a square area from } 301 \text { sq. } \\
\text { m to } 1,000 \text { sq. m or volume from } 1,501 \text { cubic } \mathrm{m} \text { to } 5,000 \text { cubic m, or } \\
\text { areas from } 10 \text { ha to } 100 \text { ha; the intervention involving simultaneous } \\
\text { deployment of } 13-36 \text { streams*), } \\
\text { - P/BD - very large-size fire (affecting items with larger square areas } \\
\text { or volumes or involved simultaneous deployment of } 37 \text { or more } \\
\text { streams*; environmental catastrophe). }\end{array}$ \\
\hline Longitude & \multirow{2}{*}{ - DMS format: degrees, minutes, seconds } \\
\hline Latitude & \\
\hline Crews & $\begin{array}{l}\text { - Number of crews present at the intervention site, } \\
\text { - A crew is formed by three to six firemen, including the chief, and is } \\
\text { equipped with an engine relevant to the task }\end{array}$ \\
\hline $\begin{array}{l}\text { Damage [thousand } \\
\text { PLN] }\end{array}$ & - Estimated damage \\
\hline Town & \multirow{3}{*}{$\begin{array}{l}\text { - Details of the town, street and building/apartment number of the } \\
\text { incident, if available. }\end{array}$} \\
\hline Street & \\
\hline $\begin{array}{l}\text { Building/apartment } \\
\text { No. }\end{array}$ & \\
\hline Object & - Descriptive value \\
\hline
\end{tabular}

* fire-fighting agent (typically water) leaving the nozzle in concentrated, dispersed or mist form Source: own work.

A range of sources was used to obtain the spatial data. For example, the voivodeship road network was downloaded from the resources of the OpenStreetMap 
service under the Open Database License (OSM), while the official administrative boundaries and the topographical site database BDOO10k for the Lódzkie Voivodeship were downloaded from the website of the Head Office of Geodesy and Cartography (GUGiK). The topographical site database was reorganised for the purposes of this study by selecting only the most relevant land cover types, summarised in Table 2 and Fig. 2.

Table 2. Land cover in Łódzkie Voivodeship in 2015 (BDOO10k), classified into major land-cover types

\begin{tabular}{|l|r|r|}
\hline \multirow{2}{*}{\multicolumn{1}{|c|}{ Land cover }} & \multicolumn{2}{c|}{ Area } \\
\cline { 2 - 3 } & $\mathbf{k m}^{\mathbf{2}}$ & Voivodeship $=\mathbf{1 0 0}$ \\
\hline Built-up area & 1519.2 & 8.3 \\
\hline Single-family housing & 1386.2 & 7.6 \\
\hline Multi-family housing & 51.4 & 0.3 \\
\hline Commercial and services area & 3.0 & 0.0 \\
\hline Industrial and warehouse zones & 48.9 & 0.3 \\
\hline Remaining & 29.7 & 0.2 \\
\hline Arable land and grassland & 11447.9 & 62.9 \\
\hline Arable land & 8281.5 & 45.5 \\
\hline Grassland & 3166.4 & 17.4 \\
\hline Permanent cultures & 338.9 & 1.9 \\
\hline Orchard & 310.5 & 1.7 \\
\hline Plantations & 21.7 & 0.1 \\
\hline Allotment gardens & 6.0 & 0.0 \\
\hline Seedbeds & 0.8 & 0.0 \\
\hline Forestry area & 4723.9 & 26.0 \\
\hline Remaining area & 164.5 & 0.9 \\
\hline Lódzkie Voivodeship & 18194.4 & 100.0 \\
\hline
\end{tabular}

Source: own work based on the data of the GUGiK.

For various reasons, a number of otherwise significant land cover types are missing from the selection adopted and these have been grouped together as the remaining area. They include water bodies, landfill sites, mines, dumps, construction sites, unused land (omitted mainly due to their small size or negligible importance from the fire-fighting perspective), or road and rail networks and associated land (omitted due to their linear nature and the geocoding precision issues mentioned above). 


\subsection{The methods}

The literature reports a number of methods of statistical and spatial analysis that have been used to identify areas susceptible to fire incidents. The simplest of these employ the weighting of threats, such as the one proposed by Eugenio et al. (2016), and Kozioł (2019). The spread of GIS techniques has made it easier to apply more advanced methods and indicators (Corcoran et al., 2007), such as the analytic hierarchy process AHP (Habibi et al., 2008; Erden and Coşkun 2010; Akay, Erdogan, 2017; Akay, Sahin, 2019), kernel density estimation, KDE (Corcoran et al., 2007; Asgary et al., 2010; Mazur, 2014), geographically weighted logistic regression (Guo et al., 2017), multiple regression (Shai, 2006), and colocation quotient (Xia et al., 2019). These studies employ a variety of factors and circumstances influencing the potential occurrence and spread of fires. Only a few studies have restricted themselves to simply considering at the actual sites of fires.

This study identifies fire high-risk areas (FH-RA) solely on the basis of the sites of actual fires of various sizes. The author has assumed that weighting alone would have made it difficult to authoritatively determine the difference in the degree of danger between fires classified by the State Fire Service as very large and small. For this reason, the analysis started by determining three different hot spots for each of the three fire size groups: small, medium, and large/very large. These three areas were then overlaid and the part of the area that was common to all three represented the output fire high-risk area (FHRA). Three fire high-risk areas were obtained generating Voronoi tessellations. The authors assumed that small-size Voronoi polygons developed in areas with high fire incidence and, therefore, small-size polygons identified fire hot spots. A threshold was adopted for the three fire size groups, below which a Voronoi polygon would be classified as small. The threshold value was derived using the Jenks natural breaks classification method. The overlap of the three fire size groups, and the outcome in the form of an identified fire high-risk area (FH-RA), is shown on Fig. 5. Voronoi polygons are widely used in solving spatial optimisation problems, especially in the identification of the reach of various services, such as emergency management, public service facilities, electric vehicle charging stations, and the middle school service (Lee and Lee, 2009; Zhu et al., 2008; Qiao et al., 2018; Wang and Kwan, 2018).

Colocations between the land cover types and the number of fire incidents were assessed using the fire location quotient (FLQ). A conceptual outline of its application to the analysis of crime distribution determinants was proposed by Sypion-Dutkowska and Leintner (2017). In spatial analysis literature, this method is reported under several variants and names (Isard, et al., 1962, p. 123; Kostrubiec, 1972, p. 21; Runge, 2006, p. 322; Suchecki, 2010). FLQ follows the formula: 


$$
F L Q_{S}^{t}=\frac{\frac{N F_{s}^{t}}{A^{t}}}{\frac{N F_{s}}{A}}
$$

where: $\mathrm{FLQ}_{\mathrm{s}}{ }^{\mathrm{t}}-$ the FLQ for fire size $s$ and land cover type $t$; $\mathrm{NF}_{\mathrm{s}}{ }^{\mathrm{t}}-$ the number of incidents for fire size $s$ within the area of land cover type (or sub-type) $t ; \mathrm{A}^{\mathrm{t}}-$ the area of land cover type (or sub-type) $t ; \mathrm{NF}_{\mathrm{s}}$ - the number of incidents for fire size $s$ within the total area; $\mathrm{A}$ - the total area; $\mathrm{T}$ - defines the 16 land cover types and subtypes $(t=1-16) ; \mathrm{S}$ - defines the number of fires in total and the three individual fire sizes $(s=1-3)$.

The FLQ determined for land cover forms and fire size groups reveals the strength and direction of the relationships linking two values. At the centre of the strength spectrum, the value of one denotes a lack or balance of influence. From this value upwards the strength of a colocation increases while from one towards zero repulsion grows. The general scheme of the methodological approach to this work is presented in Fig. 1.

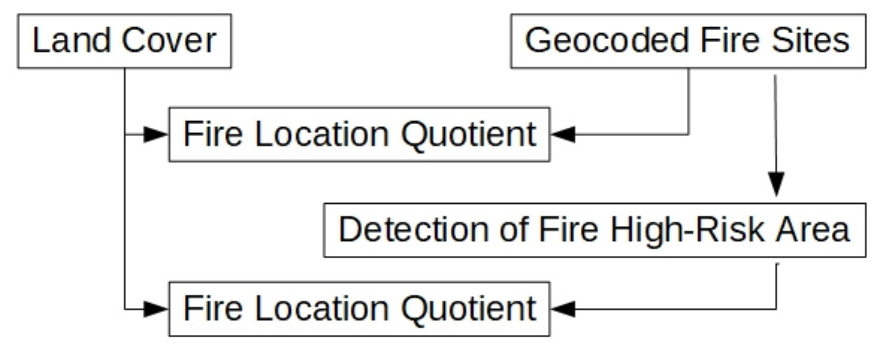

Fig. 1. Scheme of methodological approach

Source: own work.

The density of fire interventions in this study is shown using kernel density estimation (KDE). KDE produces an easily interpreted quasi-continuous fire density surface and its highest intensity identifies the fire hot spots. In this particular case, KDE provided a detailed spatial distribution of the phenomenon being studied and its concentrations. Moreover, thanks to the small grid cell size the reference surfaces offer a better alignment with the actual fire site distribution offering a good level of accuracy in the estimation of hot spots. The technique has a very strong statistical foundation and is highly modifiable, as it allows the selection of dedicated sets of parameters. This study followed the approach proposed by Hart and Zandbergen (2014) and used the following measures: density function/interpolation method - triangular, function reach/bandwidth - fixed, value: $10 \mathrm{~km}$. 


\section{ORGANISATION OF THE FIRE SERVICE IN POLAND. THE CASE STUDY AREA}

The Polish National Firefighting and Rescue System (KSRG) was established in 1995 as an integral part of the country's internal security organisation. KSRG's mission is to protect human life and health, property, and the environment, which the service does by combating fires and other localised threats and by working with medical, technical, chemical, and environmental units of the rescue system (Official Journal of 1991 No. 81 Item 351). The KSRG comprises rescue and auxiliary bodies from the State Fire Service (PSP), the Voluntary Fire Service (OSP; 4306 units in 2016) and industrial, airport, and military fire protection units (15). PSP, at its basic level, consists of Firefighting and Rescue Units (JRG; 496 units in 2016) equipped with resources to independently perform rescue missions. KSRG consisted of approximately 30,000 career PSP firefighters; more than 140,000 OSP rescuers aged 18-65 years, with more than 9000 fire fighting vehicles; and 518 rescuers with 80 various type vehicles in other fire protection units.

Łódzkie Voivodeship (NUTS 2 under EU terminology) was selected for a detailed analysis of the distribution of fire call-outs. This centrally located voivodeship occupies an area of 18,200 square kilometres (i.e. 5.8\% of Poland's territory) and has a population of 2.49 million (6.4\% of the overall population). Its capital and the largest city is Łódź with approximately 700,000 inhabitants. During the period 2014-2016, the Łódzkie Voivodeship accounted for 7.3\% of the national firefighting and rescue incidents (i.e. fires, local emergencies and false alarms), including $6.1 \%$ of all fires reported in Poland.

In 2016, the regional PSP structures in the voivodeship included: the regional headquarters, 22 district (municipal) headquarters and 34 JRG units (including 26 with more than 36 FTEs and 8 smaller ones) (Fig. 2). The PSP had 2,229 career firefighters. Beyond PSP, KSRG included 326 OSP units (plus 1,132 smaller and less well equipped OSP units outside KSRG) (all data: Information Bulletin... 2017). The largest concentration of units belonging to KSRG is found in the centre of the voivodeship, while units located in the northern and south-eastern parts are fewer and have larger service areas. The legally prescribed arrival time for rescuers in the system is between 8 and 15 minutes (Regulation of the Ministry of the Interior, Rozporzadzenie Ministra Spraw ..., 2011) and when this is impossible, the mobilisation of additional OSP units in the system should be considered.

Aside from the main line of research, the authors also analysed the arrival time of KSRG units to the various parts of the voivodeship. The highlights of these efforts, if not a detailed report, may be interesting here. KSRG units have been found to be able to reach just $49 \%$ of the voivodeship's territory (as calculated using parameters developed by Mazur et al., 2015) in the prescribed time of 15 minutes (including $22 \%$ in up to 8 minutes and $27 \%$ in 8 to 15 minutes). These 
time accessibility values varied between locations and were found to be highest in the western and central parts of the voivodeship and to diminish outwards from these areas in the direction of the voivodeship boundaries, as well as south-eastwards where the value reached its lowest point. While only less than a half of the territory could be served within the maximum time of 15 minutes, this appeared better in terms of the population. The study has calculated that areas inhabited by $73 \%$ of the population could be reached by KSRG fire-fighting units in that maximum time.

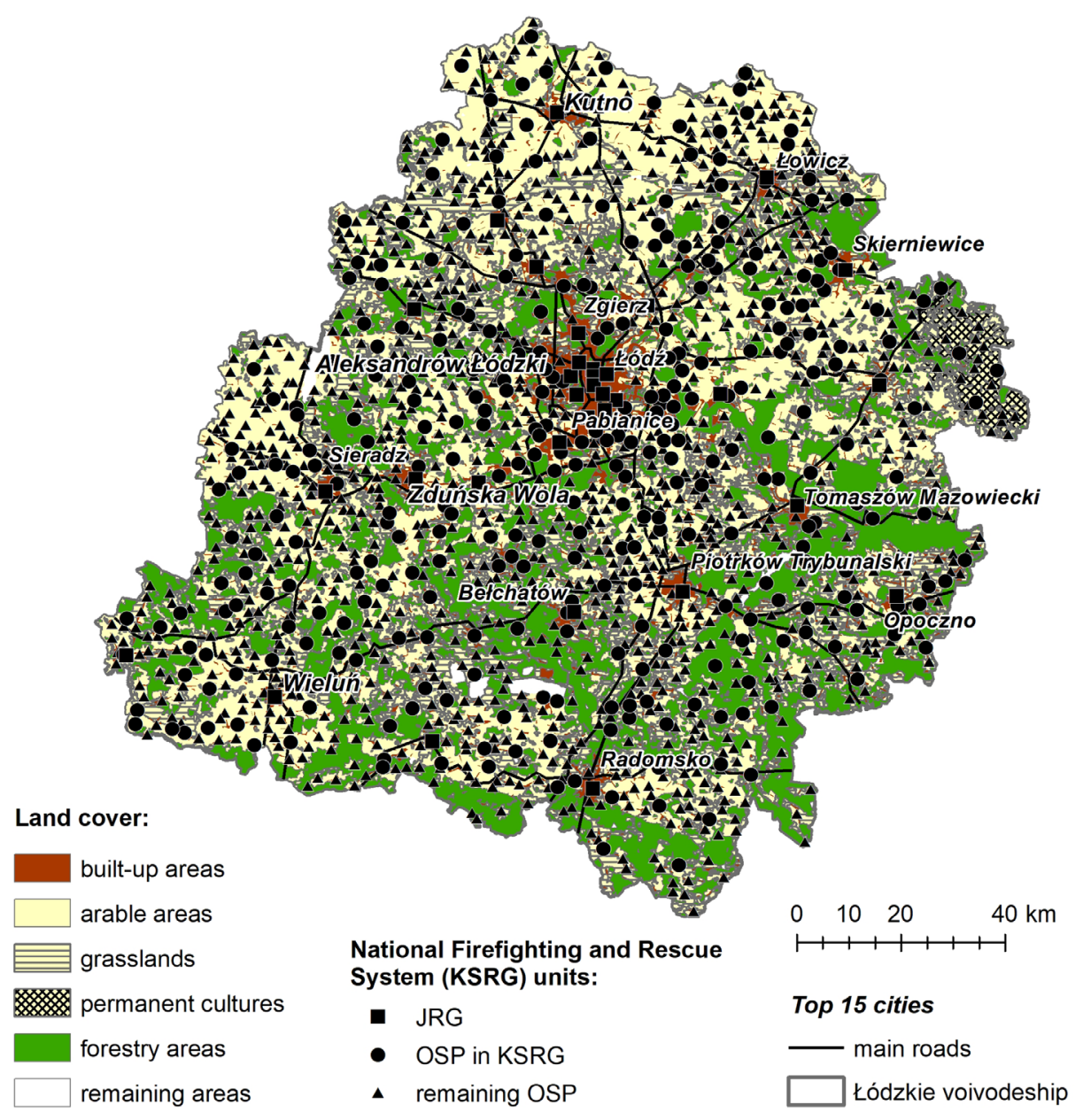

Fig. 2. Łódź voivodeship - the study area

Source: own work. 
Arable land and grasslands dominate the overall land cover composition of the voivodeship. When permanent cultures are added (Tab. 2, Fig. 2), the three types account for nearly $2 / 3$ of the territory of the voivodeship. The next important land cover type is forests, accounting for $26 \%$ of the territory. Built-up areas cover just $8.3 \%$ of the voivodeship area and consist of housing areas (7.9\%), industrial and warehouse zones $(0.3 \%)$, and commercial and services areas. According to numerous researchers from various parts of the world, it is the built-up area type that is regarded as the most at risk of fire (Asgary et al., 2010; Haas et al., 2013; Scott et al., 2013; Mazur, 2014).

\section{THE RESULTS}

\subsection{Distribution of fire sites}

The analysis of the distribution of fire sites in the Łódzkie Voivodeship was based on data provided by the Regional HQ of the State Fire Service in Łódź. Over the three-year period spanning 2014-2016, there were 27,651 fire interventions, including 11,420 in 2015 (more than 41\%), followed by 8,768 in 2014 (32\%) and 7,463 in $2016(27 \%)$. In relative terms this means that during the study period there were on average 1.5 fire incidents per square kilometre, or 0.5 fire incidents per square kilometre per annum.

Fire-fighting units were engaged throughout the study area and across the time accessibility spectrum (distribution shown in Fig. 2). It appeared, however, that there was a positive correlation between the KSRG time accessibility and the actual number of fire incidents. More than $70 \%$ of all fires during the study period occurred in areas accessible within 8 minutes and a further $18 \%$ in areas accessible in between 8 and 15 minutes. Just $12 \%$ of the total fires occurred in areas not reachable within the maximum of 15 minutes. When compared with areas of the UK or China featured in studies (Yang et al., 2001; Zhang and Jiang, 2011), the efficiency of fire unit distribution in the Łódzkie Voivodeship is quite good.

Viewed on a map (Fig. 3) fire sites congregate into a dozen areas of considerable density. The largest of these is the city of Łódź metropolitan area at the centre of the voivodeship, while smaller ones are centred on other major towns. Outside urban areas, large and medium-sized fires were recorded throughout the area. If there was a pattern to these, it would be the proximity of both large and medium-size fires to main roads and the incidence of large fires in suburban areas.

A certain number of fires covered by the study was widely publicised in the media at the time of their occurrence. For example, a large fire in June 2016 consumed the Chancellor's Building of the Lodz University of Technology. Other notable cases of sites that caught fire and public attention included a wholesale 
warehouse and a fitness club in Konstantynów Łódzki (June 2014) and the Krywań Inn in Słostowice in the south of the voivodeship (October 2016). Finally, a large fire of a warehouse hall in Skierniewice involved 191 fire-fighting crews, the largest number in a single mission (November 2014).

The concentration of the phenomenon at hand was identified by use of the Gini coefficient. Its high overall value $(G=0.74)$ suggested a highly unequal distribution, probably mainly driven by small fires $(G=0.79)$ with medium-sized events $(G=0.68)$ only slightly more equally distributed than the average. Large and very large fires had much lower Gini coefficient values ( 0.39 and 0.47 , respectively).

The trend for small fires to concentrate in town centres is not specific to this voivodeship. Similar findings were established by Mazur (2014) in Warsaw. Elsewhere, this pattern was also identified in Philadelphia, USA (Shai, 2006), Toronto, Canada (Asgary et al., 2010), Vilnius, Lithuania (Vasiliauskas and Beconyte, 2015), and the two Chinese cities of Yichun (Guo, 2017), and Nanjing (Xia et al., 2019).

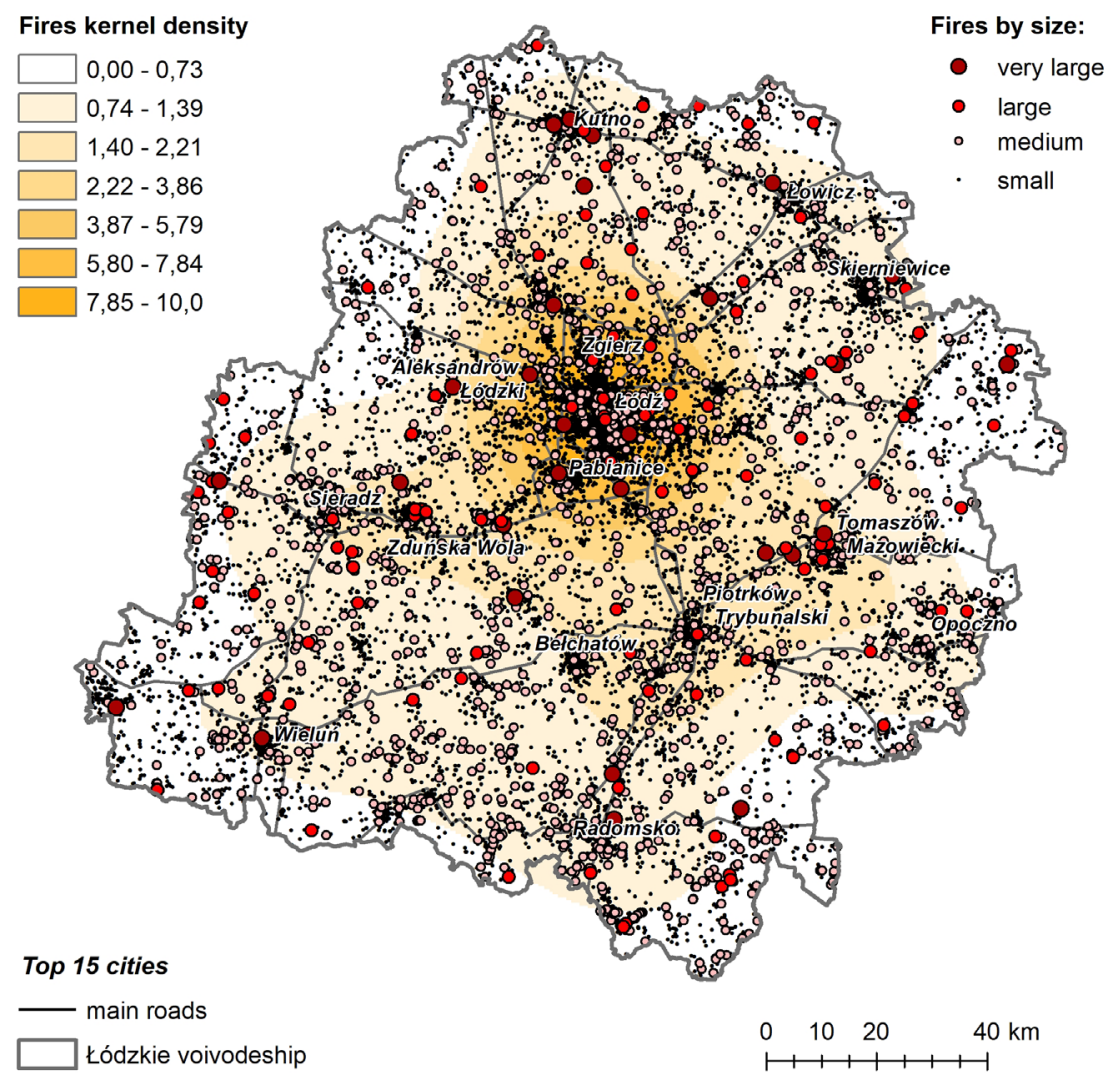

Fig. 3. Distribution and density of fire sites in the Łódzkie Voivodeship, 2014-2016 Source: own work. 
As shown in Fig. 3, the distribution of fire site density in the study area follows a clearly concentric pattern. This density reaches its peak in the regional capital, the city of Łódź, from which it diminishes outwards towards the boundaries of the voivodeship. This nearly perfect density pattern is somewhat distorted by medium sized towns: Sieradz, Zduńska Wola, Bełchatów, Piotrków Trybunalski, and Tomaszów Mazowiecki.

To provide an additional visualisation of the concentration of fire sites across the voivodeship, an anamorphic cartogram was used (Fig. 4). The fact of considering the number of fire-fighting interventions during the study period had a distorting effect on the administrative boundaries of poviats (districts). The sizes of approximately $75 \%$ of poviats were diminished and just six poviats were inflated. The most distorted is the town of Skierniewice, the territory of which has the greatest error margin (based on the distortion of the GRID projection). Łódź is the most inflated of the poviats, followed by: the poviat of Zgierz, the town of Piotrków Trybunalski, the poviat of Pabianice, the poviat of Łódź-East, and the town of Skierniewice. The lowest error margin was recorded in the poviat of Skierniewice (outside of its town part), while the most diminished territory is that of the poviat of Piotrków Trybunalski (outside of its town part).

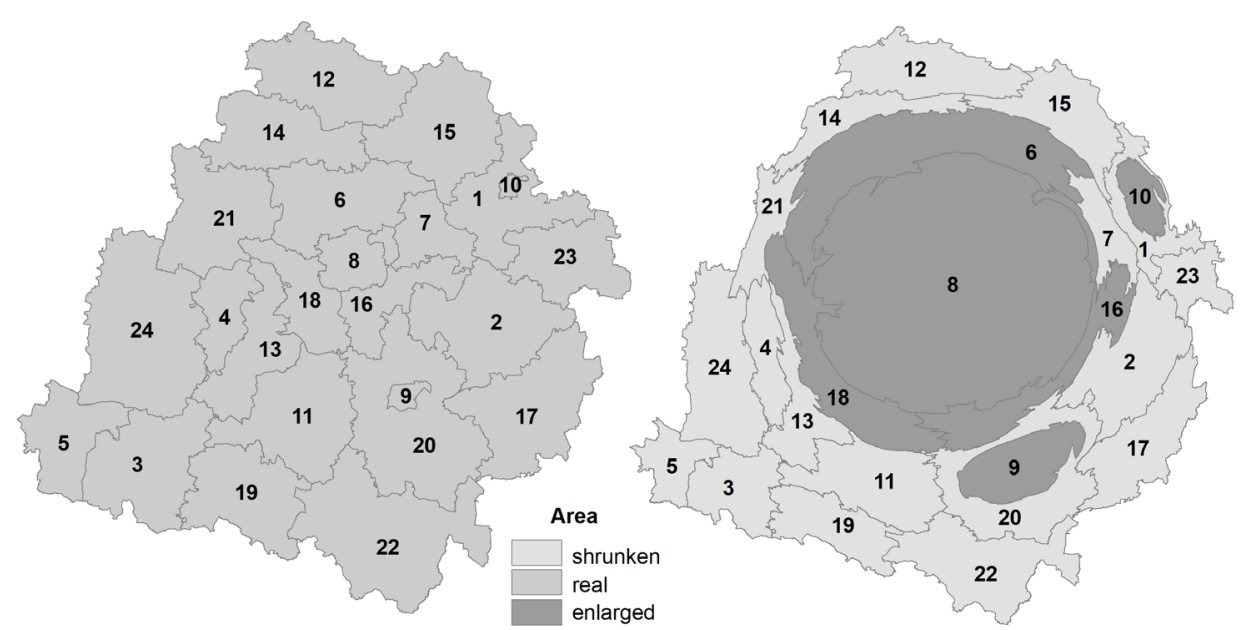

Poviats: 1. skierniewicki, 2. tomaszowski, 3. wieluński, 4. zduńskowolski, 5. wieruszowski, 6. zgierski, 7. brzeziński, 8. Łódź 9. Piotrków Trybunalski, 10. Skierniewice, 11. bełchatowski, 12. kutnowski, 13. łaski, 14. łęczycki, 15. łowicki, 16. łódzki wschodni, 17. opoczyński, 18. pabianicki, 19. pajęczański, 20. piotrkowski, 21. poddębicki, 22. radomszczański, 23. rawski, 24. sieradzki

Fig 4. Geographically accurate map of poviats (left) and the square areas of poviats taking into account the number of fire incidents recorded in the Łódź Voivodeship in 2014-2016

Source: own work using the application ScapeToad v. 11. 


\subsection{Land cover types conducive or non-conducive to fires}

There is a considerable range of variability in the FLQ-measured colocation of fires overall and of some of their size categories, and the various land cover types. This means that different land cover types have different susceptibilities to fire risk (Tab. 3). In the case of all subtypes of built-up area and of allotment gardens (a subtype of permanent cultures), this correlation can be seen to reflect conduciveness of these areas to the incidence of fires.

With their FLQ reaching extremely high values, two land cover subtypes display particularly strong conduciveness to all fire sizes: commercial and services, and multi-family housing. The very high FLQ values clearly also owe much to the small proportion that these land cover types represent in the overall area of the voivodeship, in addition to the sheer number of fires reported from these areas. They are followed by industrial and warehouse zones, remaining built-up areas, and single-family housing areas that also display strong colocations with fire sites. For these three land cover subtypes, FLQ reaches very high values for all fire sizes (with few exceptions). Other research regarding Poland and Warsaw corroborates the finding that residential areas (primarily dense urban fabric with a majority of old-style townhouses and concrete-slab housing projects) are extremely susceptible to fire risks (Mazur, 2014; Kozioł, 2019). A study of Toronto demonstrated that in addition to downtown residential areas, commercial areas along main streets, and single-family residential areas are also at risk (Asgary et al., 2010). In the Chinese city of Nanjing, high values of the colocation index (> 2.0) were obtained for various types of fire in the following land-use facility types: residential and commercial buildings, schools, green space, and entertainment and shopping sites, which results were generally compatible with the land cover types indicated in this study (Xia et al., 2019).

Table 3. FLQs of total fires and fire sizes by land cover type

\begin{tabular}{|l|c|c|c|c|}
\hline \multirow{2}{*}{\multicolumn{1}{|c|}{ Land cover }} & \multicolumn{4}{c|}{ Fire size } \\
\cline { 2 - 5 } & Total & $\begin{array}{l}\text { Large and } \\
\text { very large }\end{array}$ & Medium & Small \\
\hline Built-up area & 8.23 & 7.03 & 5.96 & 8.37 \\
\hline Single-family housing & 6.03 & 6.09 & 5.60 & 6.06 \\
\hline Multi-family housing & 57.73 & 12.82 & 8.88 & 60.89 \\
\hline Commercial and services area & 71.41 & 43.89 & 27.30 & 74.19 \\
\hline Industrial and warehouse zones & 13.50 & 29.64 & 12.69 & 13.46 \\
\hline Remaining & 9.94 & - & 4.74 & 10.30 \\
\hline Arable land and grassland & 0.39 & 0.60 & 0.65 & 0.38 \\
\hline Arable land & 0.32 & 0.57 & 0.55 & 0.31 \\
\hline Grassland & 0.57 & 0.67 & 0.91 & 0.55 \\
\hline
\end{tabular}


The influence of land cover on the spatial distribution of fire sites...

\begin{tabular}{|l|c|c|c|c|}
\hline \multirow{2}{*}{\multicolumn{1}{|c|}{ Land cover }} & \multicolumn{4}{c|}{ Fire size } \\
\cline { 2 - 5 } & Total & $\begin{array}{c}\text { Large and } \\
\text { very large }\end{array}$ & Medium & Small \\
\hline Permanent cultures & 0.28 & - & 0.38 & 0.28 \\
\hline Orchard & 0.23 & - & 0.34 & 0.22 \\
\hline Plantations & 0.12 & - & 1.08 & 0.06 \\
\hline Allotment gardens & 3.74 & - & - & 3.98 \\
\hline Seedbeds & - & - & - & - \\
\hline Forestry area & 0.22 & 0.14 & 0.30 & 0.22 \\
\hline Remaining area & 0.31 & - & 0.71 & 0.29 \\
\hline
\end{tabular}

Source: own work.

Allotment gardens form another high-risk subtype, but, uniquely, it is exclusively linked to small-sized fires. Just as in the case of built-up areas, allotment gardens involve extensive human presence and the human factor is known to be the number one cause of fires in Poland (Mazur and Kwasiborski, 2013; Mazur and Guzewski, 2014; Kozioł, 2019).

The fire risk in forests, on arable land and grasslands, on permanent cultures, and on remaining areas was low to very low. Fire concentrations in these areas across the voivodeship were very low, especially in the case of small fires. These land cover types could be perceived as non-conducive to large-size fire incidents. Only medium-sized fires in grasslands and plantations reached FLQ values close to 1 , or the average colocation value, similar to the values achieved by all land cover types in the voivodeship. It is also worth noting that certain fire sizes never occur in certain land cover areas. The low incidence of fires in agricultural areas, including grasslands, has already been indicated by Paysen et al. (2000) and Scott et al. (2013). The opposite, however, was found in the Croatian province of Dalmatia where rural areas, characterised at the same time by a high proportion of agricultural occupation and depopulation, were the ones most affected by fires. Here, grasslands and shrublands were identified as the most fire-prone land cover type (Jajtić et al., 2019). FLQ values for England and Wales quoted by Moffat and Pearce (2013) were much lower in built-up areas, but higher in arable land and grasslands, and forests.

The FLQ values obtained indicate a low fire risk in the vast forest areas in the Łódzkie Voivodeship as a whole. Paradoxically, this may partly be explained by the fact that the entire voivodeship is included in medium or high fire-risk zones designated by Lasy Państwowe, the Polish Forestry Administration. Indeed, an efficient observation and alert system has been established for this land cover type alone. The system consists of: automatic fire spotting (observation towers with CCTV), alert management points, on-ground patrols (patrols/fire-fighting 
vehicles), forest aviation bases, water abstraction points, and access roads (an adequately distributed and maintained forest road network). During risk periods, fire-spotting points actively monitor forests and flag all suspect smoke emissions to alert management points. Precision alidades are used to determine angles used in locating such smoke emissions, thus helping alert management points to accurately determine the location of a potential fire and take adequate steps (Instrukcja ochrony przeciwpożarowej lasu, 2020).

Unfortunately, this paper cannot present a thorough discussion in relation to the results obtained by other authors due to the research approach employed and the fact that the study area is not adequately represented in the literature (there are few studies relating to Central Europe that address the spatial conditions underlying the distribution of fires, in contrast to those relating to the Mediterranean area for which literature sources are very rich). Our results could be compared with the results produced with the use of a similar methodology (relationships with land cover and colocation quotient) and for an area with similar climatic conditions. The relationships between the number of fires on individual land cover types and climate zones on a global scale were well described by Schaefer and Magi (2019). Meanwhile, Bajocco et al. (2010) have proven the relationships between the number of fires on various types of land cover and three climatic subtypes distinguished in Sardinia, namely the Mediterranean, transitional Mediterranean, and transitional temperate subtypes (mainly characterised by a clear gradient of decreasing summer drought). Despite such a small research area, the above paper demonstrates that for the first climatic subtype, the relationships between the occurrence of fires and urban areas, arable lands, and permanent crops are significant. By contrast, in the other two subzones fires were more likely to occur within heterogeneous agricultural areas, forests, natural grasslands and pastures, and sclerophyllous vegetation areas. The comparisons made in the said study with the texts by Moffat and Pearce (2013), and Xia et al. (2019) do not satisfy the condition of similarity between climatic conditions, although the analyses presented there identified a relationship between the fire location and land cover. However, most of the available literature focuses on analyses of fires occurring in areas with individual land cover types, mostly urban areas (e.g. Asgary et al., 2010; Jennings, 2013) or forests (Akay and Şahin, 2019; Feurdean et al., 2020), rarely arable land (Li et al., 2017).

\subsection{Detecting fire high-risk areas (FH-RA)}

FH-RAs were obtained by generating a Voronoi tessellation. The author adopted the assumption that small polygons were indicative of short distances between fire sites thus representing high-density areas, which, in turn, could be identified as fire hot spots. The FH-RA was generated by overlaying areas with the smallest 
Voronoi polygons obtained separately for three size groups of fires: small, medium-sized, and large/very large fires (Fig. 5). This method has the benefit of generating a natural area with all groups of fires occurring close to each other without the need to convert their number into some other additional areas, i.e. without the need to design density indicators.

\section{Hot spots of:}

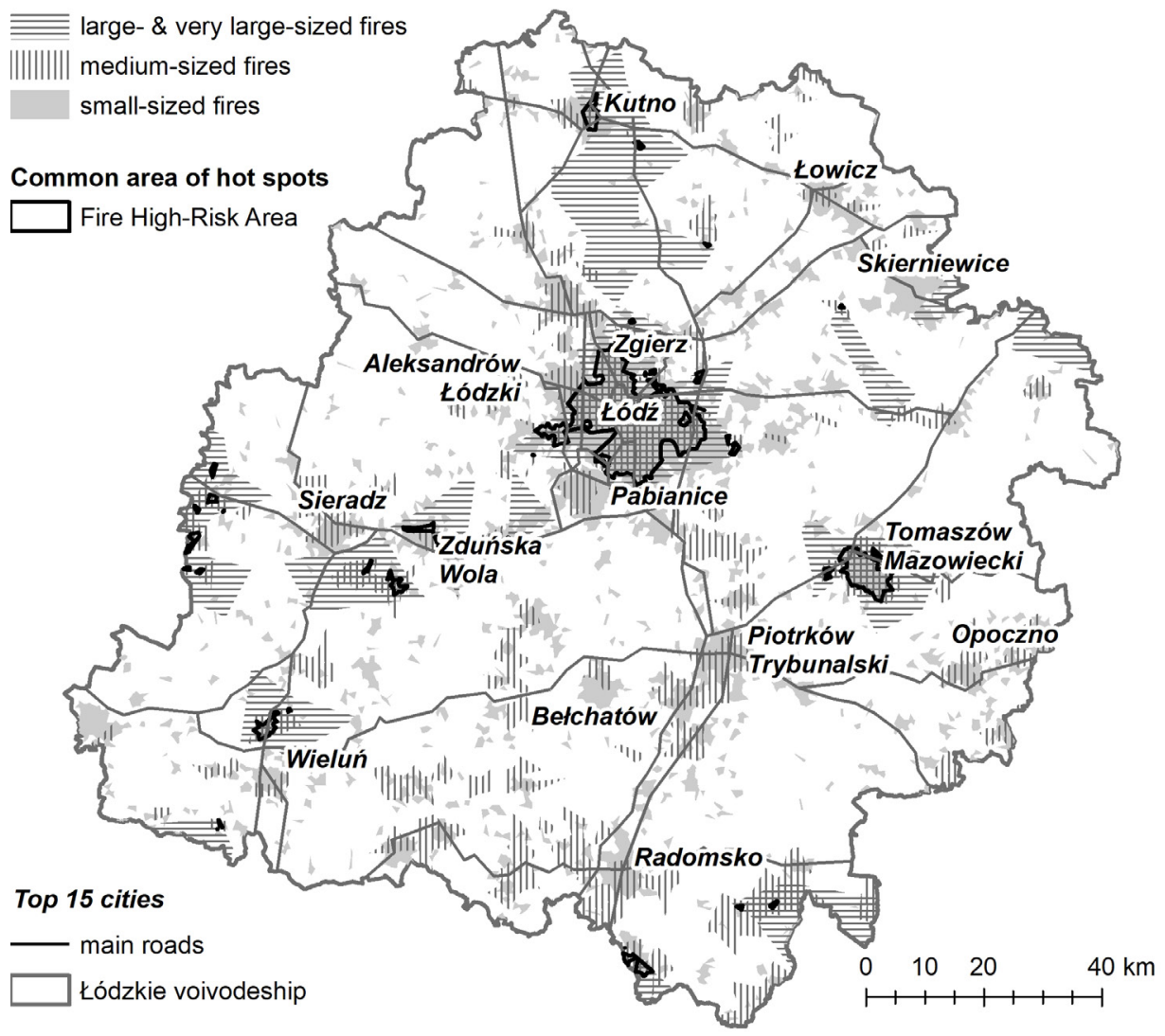

Fig. 5. Fire high-risk area (FH-RA) within Łódź voivodeship space Source: own work.

Hot spots identified for large/very large fires covered 2,512 sq. $\mathrm{km}(14 \%$ of the voivodeship area), the medium-sized fire hot spots covered 2,312 sq. km (13\%), and the ones for small fires occupied 2,650 sq. km (15\%), as depicted in Fig. 5. Those areas where hot spots of all three sizes of fire overlapped could be identified as FH-RAs. Thus determined, the FH-RAs covered 346.8 sq. km, or $1.9 \%$ of the area of the voivodeship. It was divided into 41 constituent parts, nine of 
which were bigger than 2 sq. $\mathrm{km}$. The largest portion of the FH-RAs ( 275 sq. km) included large parts of the city of Łódź and the towns of Zgierz and Konstantynów Łódzki. The next largest part of the FH-RA was much smaller and covered the town of Tomaszów Mazowiecki (43 sq. km), followed by the town of Kutno (nearly 9 sq. $\mathrm{km}$ ) and sections of the gminas (municipalities) of Czarnożyły and Ostrówek (8 sq. km north of the town of Wieluń).

The main characteristics of the fires that occurred within the FH-RAs are summarised in Tab. 4. They indicate a considerable degree of concentration of various-sized fires (nearly 24 fires per sq. km on average) within the confines of the FH-RAs, of the resulting material damage and of the involvement of fire fighting crews. The high FLQ value of 15.7 obtained for the areas indicates a serious fire risk. This risk is particularly high in the case of small fires $(\mathrm{FLQ}=16.3)$. The FLQs for medium-sized and large/very large fires, while clearly lower (at 6.3 and 7.5, respectively), still indicate that these two groups of fires are concentrated in the areas.

Table 4. Main characteristics of fires within the FH-RAs

\begin{tabular}{|l|c|c|c|c|c|c|c|}
\hline & \multicolumn{5}{|c|}{ Number (according to the size of fire) } & \multirow{2}{*}{$\begin{array}{c}\text { Damage } \\
\text { (M PLN) }\end{array}$} & $\begin{array}{c}\text { Fire-fighting } \\
\text { crews } \\
\text { engaged }\end{array}$ \\
\cline { 2 - 7 } & Total & $\begin{array}{c}\text { Very } \\
\text { large }\end{array}$ & Large & Medium & Small & 151.6 & 19102 \\
\hline FH-RAs & 8767 & 3 & 18 & 197 & 8549 & $32 \%$ & $29 \%$ \\
\hline $\begin{array}{l}\text { FH-RAs } \\
\text { as share of } \\
\text { voivodeship }\end{array}$ & $32 \%$ & $10 \%$ & $17 \%$ & $13 \%$ & $33 \%$ & $32 \%$ \\
\hline
\end{tabular}

Source: own work.

The land cover structure within the FH-RA clearly differs from that of the voivodeship as a whole. It is dominated by a built-up environment (at 58\%) at the expense of all other types of land cover. There is only $30 \%$ of arable land and grasslands (although grasslands alone have the same percentage as in the voivodeship), forests cover $11 \%$, and permanent crops occupy $1 \%$. The main components of the built-up areas include: single-family housing (41\%), multi-family housing $(9 \%)$, and industrial-warehouse zones $(5 \%)$.

FLQ values were computed for each land cover type within the FH-RA to identify the level of colocation within the area (Tab. 5). What was immediately striking was that there were much lower FLQ values for the land cover types most at risk, when compared with the values obtained for the entire voivodeship. Within the FH-RA, built-up areas showed a strong correlation with the occurrence of fires, which was even stronger in their constituent parts: commercial and services areas, and multi-family housing. Commercial and services areas, found both 
in town centres and on their peripheries, seemed conducive to fires of all sizes. Indeed, multi-family housing had a strong colocation with just the smallest fires (often just fires in waste containers, waste bin compartments, waste chutes, or vehicles). Yet industrial and warehouse zones suffered less from small fires, and a fire-fighting intervention in this type of area is normally associated with at least a medium-sized fire. The only high FLQ value in a non-built-up area was obtained for the remaining area group. This is explained by the occurrence of several medium-sized grass fires in dump areas.

Table 5. FLQs of total fires and fire sizes in land cover types within the FH-RA

\begin{tabular}{|l|c|c|c|c|}
\hline \multirow{2}{*}{\multicolumn{1}{c|}{ Land cover }} & \multicolumn{4}{c|}{ Fire size } \\
\cline { 2 - 5 } & Total & $\begin{array}{c}\text { Large and } \\
\text { very large }\end{array}$ & Medium & Small \\
\hline Built-up area & 1.61 & 1.55 & 1.45 & 1.62 \\
\hline Single-family housing & 0.98 & 1.29 & 1.24 & 0.98 \\
\hline Multi-family housing & 4.37 & 1.60 & 1.08 & 4.45 \\
\hline Commercial and services area & 6.01 & 7.91 & 5.06 & 6.02 \\
\hline Industrial and warehouse zones & 1.51 & 3.51 & 3.74 & 1.45 \\
\hline Remaining uses & 1.21 & 0.00 & 0.54 & 1.22 \\
\hline Arable land and grassland & 0.12 & 0.32 & 0.38 & 0.12 \\
\hline Permanent cultures & 0.35 & 0.00 & 0.00 & 0.36 \\
\hline Forestry area & 0.15 & 0.00 & 0.28 & 0.15 \\
\hline Remaining area & 0.45 & 0.00 & 2.34 & 0.40 \\
\hline
\end{tabular}

Source: own work.

The FH-RAs are well located in terms of accessibility. As much as $82 \%$ of their territory was reachable within 8 minutes and another $16 \%$ in between 8 and 15 minutes. Only very few sections of the area took fire-crews longer than 15 minutes to reach.

\section{CONCLUSIONS}

The main accomplishment of this study has been the identification of areas and land cover types that are actually, rather than just potentially, associated with fire risks. This was possible thanks to the use of the distribution data on actual fires geocoded at the address level. Therefore, the estimation of the risks and the colocation indices were not dependent on the internal administrative division of the 
study area, but only on the location of each fire incident and their trends to aggregate in certain areas. This has made a fundamental difference when compared to other studies where the aggregation of data at the administrative unit level has always led to a uniform treatment of those areas that, in terms of fire hazard, are far from uniform.

The authors realise that the spatial structure of fire-fighting interventions depends on a number of different characteristics: residential development, physical environment, neighbouring areas, weather, climate, and many more. In this study, however, they only explored the relationship between fire sites and land cover types from a spatial perspective. Based on their research the authors arrived at three main conclusions. Firstly, the area of the Łódź Voivodeship is not uniform in terms of fire risk, whose non-random distribution patterns are not dissimilar to ones found in numerous English-language studies published for several different areas worldwide. It is possible to pinpoint areas with more frequent fires, which, significantly, coincide with urban areas. Secondly, areas most at risk from fire are not the ones located far from the units of the fire fighting system. On the contrary, most fires occur in the parts of the voivodeship which are most quickly accessible to fire fighters. Due to the length limitations imposed on this paper the authors have only presented the highlights of their additional analysis that positively assessed the voivodeship's distribution of fire-fighting units (both professional and voluntary). Indeed, crews are able reach a large portion of the voivodeship in an adequately short time. Finally, there are strong relationships between the distribution of fire sites and land cover types. The latter have different degrees of impact on the distribution of fires across the voivodeship in general and in their size groups in particular. Built-up areas are the most at risk of fire, especially of small fires. All other land cover types have low to very low colocation values. The results of this study also support certain other pieces of published research that considered land cover types. Indeed, as found in other studies, commercial and services areas, multi-family housing, and industrial and warehouse zones proved to be the land use types conducive to the most fires. It is postulated that this analysis of the relationships between the distribution of fires and land cover types should be complemented by a study of the causes and the backgrounds of these relationships.

The objectives here were to determine the spatial relationships between the distribution of fires and land cover types using an index of colocation (i.e. the fire location quotient, FLQ), and to use the fire distribution to identify fire highrisk areas. Both objectives have been achieved. The working hypothesis that certain land cover types are either strongly conducive to fires, or vice-versa, and in this way have an impact on the distribution of fires, has been confirmed. The fire high-risk area (FH-RA) has been determined using a simple tool (Voronoi tessellation), but it does conform to the actual and frequent occurrences of fire sites. 
The results permit the formulation of certain recommendations for social policy and spatial planning. Residential areas are at too great a risk of fire. Regional and local authorities could use the sites and land cover types identified in this study to consider drafting plans to mitigate this fire hazard. From the methodological point of view, the study suggests a need to improve the PSP database to make it more useful for spatial analysis. Its main problems are incompleteness and inaccuracy. What must necessarily be done, and done urgently, is the identification of the locations of fire incidents with precise descriptions. Also, the FLQ values obtained in this study could be useful in determining the weighting of the various land cover types in any future research into the multiple factors affecting fire hazard. From this point of view, the study could contribute valuable information to the estimation of fire risks and the management of the deployment of fire service resources. The understanding of colocation patterns between fire sites and land cover types could help explain fundamental factors conducive to the development of fires. Researchers trying to identify optimum fire-fighting service networks with theoretical accessibility models could also learn that most fires do not occur in those areas where fire fighters need the longest time to arrive. The spatial analyses of fire distribution presented in this paper can be used to design the operations of fire departments in such a manner that they woud correspond to the risks they face and their two essential tasks, namely fire prevention and fire preparedness. Effective fire suppression is a last resort, which should not be allowed to happen in the first place. In line with the guidance of the Food and Agriculture Organization of the United Nations on fire prevention, it is possible to devise cost-efficient and effective fire protection programmes for any area at risk of fire. Preventing rogue fires is always less costly than suppressing them. Fire prevention programmes should be accepted and promoted within the community in order to prevent damage to goods and resources. Effective preparedness strategies include staff training and appropriate relocation of technical resources. A fire preparedness programme should be based on "fire and resource management planning", and it should consider funding for local safety tasks, weather, and risky human behaviour and activity (Fire Management ..., 2006).

The analysis of the distribution of fire call-outs in the Łódź Voivodeship has offered a preliminary confirmation to some rather obvious assumptions made about the impact of dense development on the density of fire fighting interventions. It would be difficult to add any more details to the determination of the relationships at the voivodeship level. Although this analysis certainly does not exhaust the topic of the distribution of fire fighting interventions in this voivodeship, it would be a challenge in the future to try and relate these results to smaller study areas. Such an analysis could also look at physical, climatic, and socio-demographic characteristics. Comparing such future analyses with the results of this study could offer a new perspective for the identification of fire risk areas. 


\section{REFERENCES}

AKAY, A.E. and ERDOĞAN, A. (2017), 'Gis-Based Multi-Criteria Decision Analysis For Forest Fire Risk Mapping', ISPRS Annals of the Photogrammetry, Remote Sensing and Spatial Information Sciences, IV-4/W4, pp. 25-30. https://doi.org/10.5194/isprs-annals-IV-4-W4-25-2017

AKAY, A.E. and ŞAHIN, H.T. (2019), 'Forest Fire Risk Mapping by using GIS Techniques and AHP Method: A Case Study in Bodrum (Turkey)', European Journal of Forest Engineering, 5 (1), pp. 25-35. https://doi.org/10.33904/ejfe.579075

ASGARY, A., GHAFFARIA, A. and LEVY, J. (2010), 'Spatial and temporal analyses of structural fire incidents and their causes: A case of Toronto, Canada', Fire Safety Journal, 45 (1), pp. 44 57. https://doi.org/10.1016/j.firesaf.2009.10.002

BAJOCCO, S., PEZZATTI, G.B., MAZZOLENI, S. and RICOTTA, C. (2010), 'Wildfire seasonality and land use: when do wildfires prefer to burn?', Environmental Monitoring and Assessment, 164 (1-4), pp. 445-452. https://doi.org/10.1007/s10661-009-0905-x

CORCORAN, J., HIGGS, G., BRUNSDON, C., WARE, A. and NORMAN, P. (2007), 'The use of spatial analytical techniques to explore patterns of fire incidence: A South Wales case study', Computers, Environment and Urban Systems, 31 (6), pp. 623-647. https://doi.org/10.1016/j. compenvurbsys.2007.01.002

DLAMINI, W.M. (2011), 'Application of Bayesian networks for fire risk mapping using GIS and remote sensing data', GeoJournal, 76 (3), pp. 283-296. https://doi.org/10.1007/s10708-0109362-x

ERDEN, T. and COŞKUN, M.Z. (2010), 'Multi-criteria site selection for fire services: the interaction with analytic hierarchy process and geographic information systems', Natural Hazards and Earth System Sciences, 10, pp. 2127-2134. https://doi.org/10.5194/nhess-10-2127-2010

EUGENIO, F.C., dos SANTOS, A.R., FIEDLER, N.C., RIBEIRO, G.A., da SILVA, A.G., dos SANTOS, A.B., PANETO, G.G. and SCHETTINO, V.R. (2016), 'Applying GIS to develop a model for forest fire risk: A case study in Espirito Santo, Brasil', Journal of Environmental Management, 173, pp. 65-71. https://doi.org/10.1016/j.jenvman.2016.02.021

FEURDEAN, A., VANNIÈRE, B., FINSINGER, W., WARREN, D., CONNOR, S.C., FORREST, M., LIAKKA, J., PANAIT, A., WERNER, C., ANDRIČ, M., BOBEK, P., CARTER, V.A., DAVIS, B., DIACONU, A.-C., DIETZE, E., FEESER, I., FLORESCU, G., GAŁKA, M., GIESECKE, T., JAHNS, S., JAMRICHOVÁ, E., KAJUKAŁO, K., KAPLAN, J., KARPIŃSKAKOŁACZEK, M., KOŁACZEK, P., KUNEŠ, P., KUPRIYANOV, D., LAMENTOWICZ, M., LEMMEN, C., MAGYARI, E.K., MARCISZ, K., MARINOVA, E., NIAMIR, A., NOVENKO, E., OBREMSKA, M., PĘDZISZEWSKA, A., PFEIFFER, M., POSKA, A., RÖSCH, M., SŁOWIŃSKI, M., STANČIKAITĖ, M., SZAL, M., ŚWIĘTA-MUSZNICKA, J., TANŢĂU, I., THEUERKAUF, M., TONKOV, S., VALKÓ, O., VASSILJEV, J., VESKI, S., VINCZE, I., WACNIK, A., WIETHOLD, J. and HICKLER, T. (2020), 'Fire hazard modulation by long-term dynamics in land cover and dominant forest type in Eastern and Central Europe', Biogeosciences, 17, pp. 1213-1230. https://doi.org/10.5194/bg-17-1213-2020

Fire management: voluntary guidelines. Principles and strategic actions (2006), Rome: FAO. http:// www.fao.org/3/j9255e/j9255e00.pdf [accessed on: 03.09.2020].

GUO, F., SU, Z., TIGABU, M., YANG, X., LIN, F., LIANG, H. and WANG, G. (2017), 'Spatial Modelling of Fire Drivers in Urban-Forest Ecosystems in China', Forests, 8, p. 180.

HAAS, J.R., CALKIN, D.E. and THOMPSON, M.P. (2013), 'A national approach for integrating wildfire simulation modeling into Wildland Urban Interface risk assessments within the United States', Landscape and Urban Planning, 119, pp. 44-53. https://doi.org/10.1016/j.landurbplan.2013.06.011 
HABIBI, K., LOTFI, S. and KOOHSARI, M.J. (2008), 'Spatial Analysis of Urban Fire Station Location by Integrating AHP Model and IO Logic Using GIS (A Case Study of Zone 6 of Tehran)', Journal of Applied Sciences, 8 (19), pp. 3302-3315. https://doi.org/10.3923/jas.2008.3302.3315

HART, T. and ZANDBERGEN, P. (2014), 'Kernel density estimation and hotspot mapping: Examining the influence of interpolation method, grid cell size, and bandwidth on crime forecasting', Policing: An International Journal of Police Strategies \& Management, 37 (2), pp. 305-323. https://doi.org/10.1108/PIJPSM-04-2013-0039

HASTIE, C. and SEARLE, R. (2016), 'Socio-economic and demographic predictors of accidental dwelling fire rates', Fire Safety Journal, 84, pp. 50-56. https://doi.org/10.1016/j.firesaf.2016.07.002

HOLBORN, P.G., NOLAN, P.F. and GOLT, J. (2003), 'An analysis of fatal unintentional dwelling fires investigated by London Fire Brigade between 1996 and 2000', Fire Safety Journal, 38 (1), pp. 1-42. https://doi.org/10.1016/S0379-7112(02)00049-8

HUANG, B., LIU, N. and CHANDRAMOULI, M. (2006), 'A GIS supported Ant algorithm for the linear feature covering problem with distance constraints', Decision Support Systems, 42 (2), pp. 1063-1075. https://doi.org/10.1016/j.dss.2005.09.002

Information Bulletin Of The State Fire Service For The Year 2016 (2017). http://www.straz.gov.pl/ download/4022 [accessed on: 15.03.2020].

Instrukcja ochrony przeciwpożarowej lasu, (2020), Warszawa: Centrum Informacyjne Lasów Państwowych. http://www.lasy.gov.pl/pl/publikacje/copy_of_gospodarka-lesna/ochrona_lasu/ instrukcja_p-poz.pdf [accessed on: 11.02.2020].

ISARD, W., BRAMHALL, D.F., CARROTHERS, G.A.P., CUMBERLAND, J.H., MOSES, L.N., PRICE, D.O. and SCHOOLER, E.W. (eds.) (1962), Methods of Regional Analysis: An Introduction to Regional Science, Cambridge: M.I.T. Press.

JAJTIĆ, K., GALIJAN, V., ŽAFRAN, I. and CVITANOVIĆ, M. (2019), 'Analysing Wildfire Occurrence Through A Mixed-Method Approach: A Case Study From The Croatian Mediterranean', Erdkunde, 73 (4), pp. 323-341. https://doi.org/10.3112/erdkunde.2019.04.05

JENNINGS, C.R. (2013), 'Social and economic characteristics as determinants of residential fire risk in urban neighborhoods: A review of the literature', Fire Safety Journal, 62, pp. 13-19. https://doi.org/10.1016/j.firesaf.2013.07.002

KOSTRUBIEC, B. (1972), 'Analiza zjawisk koncentracji w sieci osadniczej. Problemy metodyczne', Prace Geograficzne, 93.

KOZIOł, J. (2019), 'Mapowanie rozkładu pożarów i miejscowych zagrożeń na przykładzie województwa mazowieckiego', Safety \& Fire Technology, 54 (2), pp. 22-31. https://doi.org/10.12845/ sft.54.2.2019.2

LEE, I. and LEE, K. (2009), 'A generic triangle-based data structure of the complete set of higher order Voronoi diagrams for emergency management', Computers, Environment and Urban Systems, 33, pp. 90-99. https://doi.org/10.1016/j.compenvurbsys.2009.01.002

LI, Y., ZHAO, J., GUO, X., ZHANG, Z., TAN, G. and YANG, J. (2017), 'The Influence of Land Use on the Grassland Fire Occurrence in the Northeastern Inner Mongolia Autonomous Region, China', Sensors, 17 (3), p. 437. https://doi.org/10.3390/s17030437

MAZUR, R. (2014), 'Ocena stopnia bezpieczeństwa w aspekcie statystyk zdarzeń za lata 20002012. Czasowo-przestrzenna charakterystyka zagrożeń pożarowych obiektów mieszkalnych w systemie informacji przestrzennej (GIS) na przykładzie m.st. Warszawa', BiTP. Bezpieczeństwo i Technika Pożarnicza, 34 (2), pp. 47-56.

MAZUR, R. and GUZEWSKI, P. (2014), 'Ocena stopnia bezpieczeństwa w aspekcie statystyk zdarzeń za lata 2000-2012. Analiza statystyczna przypuszczalnych przyczyn pożarów obiektów mieszkalnych w skali kraju i miasta', Bezpieczeństwo i Technika Pożarnicza, 35 (3), pp. 47-59. 
MAZUR, R. and KWASIBORSKI, A. (2013), 'Ocena stopnia bezpieczeństwa w aspekcie statystyk zdarzeń za lata 2007-2012. Pożary’, Bezpieczeństwo i Technika Pożarnicza, 30 (2), pp. 17-22.

MAZUR, R., PAJĄK, M., KŁOSIŃSKI, M. and KLECHA, P. (2015), 'Koncepcja budowy i zastosowania infrastruktury danych przestrzennych w aspekcie planowania operacyjnego Państwowej Straży Pożarnej. Studium przypadku na podstawie województwa świętokrzyskiego’, [in:] WRÓBLEWSKI, D. (ed.). Zarządzanie kryzysowe Wybrane wyniki badań naukowych i prac rozwojowych, Józefów: Centrum Naukowo-Badawcze Ochrony Przeciwpożarowej, Państwowy Instytut Badawczy, pp. 128-147.

MOFFAT, A.J. and PEARCE, H.G. (2013), Harmonising approaches to evaluation of forest fire risk, A report by Forest Resarch \& Scion, supported by Tranzfor, Farnham.

NIMLYAT, P.S., AUDU, A.U., OLA-ADISA, E.O. and GWATAU, D. (2017), 'An evaluation of fire safety measures in high-rise buildings in Nigeria', Sustainable Cities and Society, 35, pp. 774785. https://doi.org/10.1016/j.scs.2017.08.035

PAYSEN, T.E., ANSLEY, R.J., BROWN, J.K., GOTTFRIED, G.J., HAASE, S.M., HARRINGTON, M.G., NAROG, M.G., SACKETT, S.S. and WILSON, R.C. (2000), 'Fire in western shrubland, woodland, and grassland ecosystems', [in:] BROWN, J.K. and SMITH, J.K. (eds.), Wildland fire in ecosystems: effects of fire on flora, Fort Collins: U.S. Department of Agriculture, Forest Service, Rocky Mountain Research Station, pp. 121-159.

Podręcznik Użytkownika Systemu SWD-ST 2.5 (2014). https:/www.swdst.pl/wp-content/uploads/ pliki/ instrukcja_swd_st_2.5.pdf [accessed on: 15.03.2020].

QIAO, Y., HUANG, K., JEUB, J., QIAN, J. and SONG, Y., (2018), 'Deploying electric vehicle charging stations considering time cost and existing infrastructure', Energies, 11, p. 2436. https://doi.org/10.3390/en11092436

Rozporzadzenie Ministra Spraw Wewnętrznych i Administracji z dnia 18 lutego 2011 r.w sprawie szczegółowych zasad organizacji krajowego systemu ratowniczo-gaśniczego (Dz.U. $2011 \mathrm{nr}$ 46, poz. 239).

RUNGE, J. (2006), Metody badań w geografii społeczno-ekonomicznej - elementy metodologii, wybrane narzędzia badawcze, Katowice: Wydawnictwo Uniwersytetu Śląskiego.

SCHAEFER, A.J. and MAGI, B.I. (2019), 'Land-Cover Dependent Relationships between Fire and Soil Moisture', Fire, 2, p. 55. https://doi.org/10.3390/fire2040055

SCOTT, J.H., THOMPSON, M.P. and CALKIN, D.E. (2013), A wildfire risk assessment framework for land and resource management, Fort Collins: U.S. Department of Agriculture, Forest Service, Rocky Mountain Research Station. https://doi.org/10.2737/RMRS-GTR-315

SHAI, D. (2006), 'Income, Housing, and Fire Injuries: A Census Tract Analysis', Public Health Reports, 121 (2), pp. 149-154. https://doi.org/10.1177/003335490612100208

SUCHECKI, B. (2010), Ekonometria przestrzenna. Metody i modele analizy danych przestrzennych, Warsaw: Wydawnictwo C.H. Beck.

SYPION-DUTKOWSKA, N. and LEITNER, M. (2017), 'Land Use Influencing the Spatial Distribution of Urban Crime: A Case Study of Szczecin, Poland', ISPRS International Journal of Geo-Information, 6 (3), pp. 74. https://doi.org/10.3390/ijgi6030074

Ustawa z dnia 24 sierpnia 1991 r. o ochronie przeciwpożarowej (Dz.U. $1991 \mathrm{nr}$ 81, poz. 351).

VASILIAUSKAS, D. and BECONYTE, G. (2015), 'Spatial analysis of fires in Vilnius city in 20102012', Geodesy and Cartography, 41 (1), pp. 25-30. https://doi.org/10.3846/20296991.2015.1 011862

WANG, J. and KWAN, M. (2018), 'Hexagon-based adaptive crystal growth Voronoi diagrams based on weighted planes for service area delimitation', ISPRS International Journal of Geo-Information, 7 (7), p. 257. https://doi.org/10.3390/ijgi7070257

WOŹNIAK, E. (2014), 'Określanie metodami geoinformatycznymi stopnia zagrożenia pożarowego lasów w Polsce’, Teledetekcja Środowiska, 51, pp. 5-55. 
XIA, Z., LI, H., CHEN, Y. and YU, W. (2019), 'Detecting urban fire high-risk regions using colocation pattern measures', Sustainable Cities and Society, 49, p. 101607. https://doi.org/10.1016/j. scs.2019.101607

YANG, L., JONES, B.F. and YANG, S. (2007), 'A fuzzy multi-objective programming for optimization of fire station locations through genetic algorithms', European Journal of Operational Research, 181 (2), pp. 903-915. https://doi.org/10.1016/j.ejor.2006.07.003

ZHANG, W. and JIANG, J.C. (2011), 'Research on the location of fire station based on GIS and GA', Applied Mechanics and Materials, 130-134, pp. 377-380. https://doi.org/10.4028/www. scientific.net/AMM.130-134.377

ZHU, H.H., YAN, H.W. and LI, Y. (2008), 'An optimization method for the layout of public service facilities based on Voronoi diagrams', Science of Surveying and Mapping, 33, pp. 72-74. 